\title{
Tax Competition in the Regions of the North Caucasus Federal District: Targets and Tools for Implementation
}

\author{
Elena M. Dzhurbina* \\ Dmitriy I. Fateev
}

North Caucasus Federal University; *Corresponding Email: dem0608@mail.ru

\section{Doi:10.5901/mjss.2015.v6n6s7p71}

\begin{abstract}
The article examines the theoretical aspects of the manifestation of tax competition at the regional level, and specifics of its practical implementation by the example of subjects of the North Caucasus Federal District. The conclusions are made on the transformation of targets of tax competition and the mechanisms of its implementation in the conditions of hyper-concentration of tax powers at the federal level. This is related to the practice of fixing the low efficiency of the tax administration in the region, while compensating the 'drop out' of income through financial aid from the federal budget.
\end{abstract}

Keywords: tax competition, fiscal federalism, tax breaks, tax collection, intergovernmental transfers

\section{Introduction}

Architectonics of the fiscal system of a federal state is characterized by a complex interaction of three or more economically isolated levels, ideally using their own tools to generate tax revenue. This situation is supposed to give the sub-federal authorities the power to self-regulation of the individual elements of the fiscal architecture. This, in addition to increasing interest in socio-economic development of the territories under their control, initiates a number of additional external effects, the result of the impact of which on the performance of tax and inter-budgetary relations cannot be interpreted in a uniquely positive manner.

Similar ambiguous effect can be confidently attributed to such a phenomenon as inter-regional tax competition. In the most general form it is defined as the use of tax instruments (in the form of lower tax rates and fringe benefits) in order to attract new economic entities (i.e. firms and skilled labor) and additional financial resources (i.e. investments) to the region (Wilson, 1999). Despite evidence on targets settings of the tax competition, its impact on the fiscal efficiency of the public finance system is controversial and requires extensive theoretical and applied analysis.

\section{Review of Theoretical Models of Tax Competition}

Genesis of theoretical views on the issues of tax competition should be carried out building on the research of Tiebout (1956), one of the first to substantiate the thesis that the fiscal autonomy at the subnational level enables for the formation of individualized and close to optimal 'mix' of taxes and budget expenditures. Territorial mobility of people contributes to effective competition between the territories that seek to ensure a significant inverse relationship between the volume of provided public goods and the value of tax rates, attracting this way a skilled workforce and citizens with a high level of personal income (Tiebout, 1956).

Despite the efficiency of the aforementioned approach, it has not received a significant development in contemporary literature, giving way to views of Bradford and Oates (1971), who proved that the competition between the regions leads to the establishment of lower tax rates, contributing to the movement of mobile factors of production in these jurisdictions. As a result, there is a negative trend of a 'race to the bottom', according to which the reduction in the fiscal burden leads to a significant reduction in the production of public goods (Bradford \& Oates, 1971). Debatable issue in the model of Bradford and Oates is an exclusively negative interpretation of the downsizing of the public sector as a result of tax competition, since a hypothesis about the dangers of low tax rates is relevant only in the framework of the 'State - Benevolent dictator', implying orientation to maximize social welfare.

However, this claim was subject to doubt in the theory of the 'public choice' developed by Buchanan and Brennan (1980). The scientists introduced the concept of 'State - Leviathan', which tends to increase the fiscal burden not to 
maximize the production of public goods but in order to finance the growing needs of authorities and its own officials (Brennan \& Buchanan, 1980).

Formal verification of the above theoretical positions was implemented only in the late 1980s. In particular, in the works of Wilson (1986), Zodrow and Mieszkowski (1986), hereinafter, their formalized point of view is called WZM-model. The Government is considered as being 'friendly' agent to the society, as a result of which it becomes possible both the tax competition and a 'shift' of fiscal pressure in favor of the non-mobile objects, such as real estate, while the tax rates for mobile factors of production (i.e. capital and partly labor) are reduced as a result of the active policy of the regions to attract them (or 'aspire to the bottom' if you use a literal conceptual apparatus of foreign scholars characterizing tax competition).

This interregional tax competition countrywide does not lead to a global reduction in tax revenues and 'compression' of the public sector for the following reasons. Potential 'drop out' income of an individual region is partially offset by the 'influx' of mobile factors of production and new tax bases. Such in-country 'migration' contributes to the extensive increase in fiscal capacity of the 'host' territory, with the regions - 'donors' being forced, ceteris paribus, to develop in lose-lose situation of 'export' of its own tax potential. As a result, sub-federal authorities are facing fundamental choice of the imperatives of fiscal policy: to lower the level of fiscal pressure and bring additional revenue sources or to increase tax rates, taking into account the likely reduction in the total taxable resources of the territory.

Formal models based on the hypothesis of 'State - Leviathan', developed by Edwards and Keen (1996), suggest that each territorial entity always seeks to maximize its own tax revenues, but the possibility of inter-territorial migration to regions with lower fiscal burden reduces the equilibrium tax rates throughout the country. Thus, tax competition is one of the effective barriers of uncontrolled expansion of the public sector and, therefore, its impact on the overall economic situation is recognized as positive (Edwards \& Keen, 1996).

In spite of the presented theoretical discrepancies, the scientific community still inclined to think of the negative impact of tax competition on the efficiency of public goods, since the establishment of the rates of taxation of mobile factors of production at a level below the optimum leads to a lack of budget resources of the territory. Subsequent studies in the framework of WZM-model focused on various aspects of economic relations, particularly inter-regional trade in goods and services. As a result, it was formed and proved the hypothesis that differences in the level of taxation of capital contribute to an inefficient allocation of public goods and reduce the efficiency of trade transactions for a total unchanged level of fiscal pressure.

Wildasin (1988) has shifted a research focus from the model of pure competition with many interacting agents to a small number of local jurisdictions. He proved that if public spending is a variable of strategic choice of local fiscal policy, according to which tax rates are applicable, the latter can be considered as 'strategic substitutes'. In this case, the reduction of fiscal pressure in one municipality assumes its automatic increase in the other, since maintaining a predetermined level of budget expenditures under 'shortfall' of tax bases in favor of more 'loyal' jurisdiction relates to an increase in tax rates (Wildasin, 1988).

A certain novelty to study problems of tax competition was introduced in the framework of the so-called 'New Economic Geography', which emphasizes the benefits of agglomeration of individual regions. The presence of these benefits provides economic entities engaged in economic and financial activities within these areas, with higher revenues, and fiscal authorities - to impose them on the increased tax rates, i.e. a consequence of tax competition is not a reduction (as it is in WZM-model), but the relative increase in tax exemptions (Baldwin \& Krugman, 2004).

Recent research in the field of tax competition aimed at studying the dependence of the latter on the specific characteristics of the public sector operations, for example, the current system of vertical and horizontal inter-budgetary alignment. Fenge and Wrede (2007) theoretically prove that the incentives to participate in the processes of interterritorial tax competition decline given the availability of an effective mechanism for fiscal equalization. This conclusion is based on formal modeling of tax rates, the equilibrium value of which is higher given the existence of a transparent methodology for determining intergovernmental transfers the financial system of the state based on the index of budgetary expenditure and tax capacity (Fenge \& Wrede, 2007).

Thus, the economic effects and externalities of tax competition in the federal states remain controversial and poorly understood, since even a value judgment about the benefits / dangers of this process depends on the originally chosen conceptual characteristics of the state and its corresponding formal model of behavior ('benevolent dictator' or 'Leviathan'). This uncertainty manifests itself markedly, firstly, in the study of whether tax competition contributes to the reduction of budget revenues. At the same time, despite the mixed results of theoretical research, it appears that the possibility of competitive interaction of regions in the tax area is one of the important factors of the fiscal constraints of sub-federal authorities' 'appetite'. This assertion is proved in the earliest studies on the specified issues, which are based on the consideration of tax rates as 'strategic substitutes' in the system of fiscal policy measures. It appears that the 
delimitation of the tax burden may even be desirable in terms of insufficient public sector (i.e. 'State - Leviathan').

\section{Peculiarities of Tax Competition in the Regions of the North Caucasus Federal District}

Russia's experience in building tax federalism demonstrates the lack of effectiveness of the chosen model of its organization on the basis of the same symmetrical distribution of fiscal powers. Given the sharply differentiated economic structure of the territorial entities, it contributes to the unprecedented heterogeneity of parameters in fiscal effectiveness.

This fact leads to the emergence of specific forms of vertical (i.e. between levels of the budgetary system) and horizontal (i.e. between regions) tax competition, and the aforementioned approaches to the definition of its objectives, tools of implementation and effects in the Russian conditions seem to be insufficiently operational. Specifics of tax competition in the regions of North Caucasus Federal District is the transformation of its targets and the underlying instruments, being associated not only with lower tax rates and further benefits, but also to the development of the practice of low efficiency of tax administration, which, in general, provide a pronounced reduction of the fiscal burden.

Preceding the structural and quantitative analysis of the features of the implementation of tax competition of the subjects of North Caucasian Federal District, one should focus on the most important characteristic of the use of their socio-economic and budgetary potential, namely the level of subsidization of sub-federal budget, which is calculated on the basis of determining the share of financial aid in its total income. The importance of this indicator is defined by its dual role: it simultaneously acts as an indicator of the quality of governance of territorial finances and as one of the basic guidelines in the implementation of competition in the area of taxation.

From this point of view, practically all regions of North Caucasus Federal District show a significant excess of the average level of subsidies, ranged from $23.1 \%$ in 2010 to $19.3 \%$ in 2013, while in the regions of the county (except for the Stavropol Territory), the transfers provide more than $50 \%$ of revenues, reaching $85 \%$ in the Republic of Ingushetia (Table 1).

Table 1. The level of subsidization of the consolidated budgets of subjects of the North Caucasus Federal District and countrywide

\begin{tabular}{lcccc}
\hline & \multicolumn{3}{c}{ The share of financial aid in the total revenues of the consolidated regional budget, \% } \\
\cline { 2 - 4 } & 2010 & 2011 & 2012 & 2013 \\
\hline Republic of Dagestan & 73.7 & 74.0 & 72.2 & 70.0 \\
Republic of Ingushetia & 89.0 & 83.8 & 86.4 & 85.0 \\
Kabardino-Balkar Republic & 54.0 & 59.0 & 55.6 & 56.2 \\
Karachay-Cherkess Republic & 68.2 & 63.9 & 72.9 & 68.5 \\
Republic of Northern Ossetia-Alania & 60.0 & 58.8 & 59.3 & 56.3 \\
Chechen Republic & 86.6 & 86.9 & 85.1 & 81.4 \\
Stavropol Krai & 33.9 & 38.1 & 33.8 & 33.6 \\
Total countrywide & 23.1 & 23.1 & 20.8 & 19.3 \\
\hline
\end{tabular}

Source: (Federal State Statistics Service, 2014).

Without going into detail about the reasons for subsidization of economic subjects of the federation, we only note that the fluctuations taking place are not always determined by the factors related to the objective ability of the region to mobilize financial resources in the budget system. Often a significant role in fixing the fiscal imbalance plays the current system of distribution of tax revenues, as well as the transfer of additional authority on expenditure without adequate sources of funding. This situation leads to an increase in the fiscal burden on the regional economy, which limits their ability to expanded reproduction and reduces the incentives for the implementation of tax competition, irrespective of the theoretical concept of operations of subnational governments taken into account ('benevolent dictator' or 'Leviathan').

The development potential of tax competition is determined primarily by the presence of the adequate tax powers of regional authorities to take decisions on reducing the fiscal pressure on the basis of regulation of the essential elements of taxation: the tax base, rates and exemptions. The Russian model of fiscal system is based on hyperconcentration of tax powers at the federal level, with the virtual absence of appropriate instruments of fiscal regulation at the disposal of regional and local authorities. This is defined both by very low fiscal 'power' of sub-federal taxes (their combined share does not exceed 5-7\% in the budgets of the most prosperous regions in economic terms), and the limited powers on establishing and changing their essential elements, the content of which is reduced to regulation of rates and benefits in tough limits that are set by federal law. 
Taking into account the provisions above, one can come to the erroneous conclusion that the current system of fiscal federalism makes it impossible for the implementation of 'maneuvers' in the framework of participation in the interregional tax competition. However, the analysis of empirical data suggests that subjects of the North Caucasus Federal District do not effectively use fiscal capacity of regional and local taxes, which contribute the reduction of both the tax burden and the revenues of regional budgets.

Qualitative analysis of the characteristics of the tax incentives provided with regard to compliance with the objectives of attracting investment and enhancing business activity gives an indication that most of them are set mostly within the framework of common principles of taxation being invariant to the need of achieving the traditional goals of tax competition.

Table 2 shows the ratio of tax benefits set by the federal and regional (local) levels to the amount of current incomes under the relevant tax, i.e. determined the share of 'shortfall' budget revenues, arising from the fiscal decisions of subnational government entities of the North Caucasus Federal District.

Table 2. The share of benefits in the total value of sub-federal tax revenues across regions of the North Caucasus Federal District and countrywide in 2012, \%

\begin{tabular}{lccccc}
\hline & \multicolumn{2}{c}{ Corporate Property Tax } & Transport tax & \multicolumn{2}{c}{ Land tax } \\
\cline { 2 - 5 } & \multicolumn{4}{c}{ The level of exemptions regulation } \\
\cline { 2 - 5 } & Federal & Regional & Federal & Regional & Local \\
\hline Republic of Dagestan & 55.05 & 1.31 & 55.49 & 1.09 & 3.37 \\
Republic of Ingushetia & 10.52 & 4.40 & 11.11 & 0.13 & 5.07 \\
Kabardino-Balkar Republic & 24.64 & 50.73 & 8.18 & 6.18 & 96.00 \\
Karachay-Cherkess Republic & 18.27 & 36.74 & 31.75 & 13.39 & 48.06 \\
Republic of Northern Ossetia-Alania & 54.94 & 16.46 & 1.06 & 5.62 & 12.64 \\
Chechen Republic & 10.03 & 49.92 & 47.71 & 2.19 & 40.32 \\
Stavropol Krai & 36.90 & 6.35 & 10.69 & 2.42 & 5.33 \\
Total countrywide & 38.86 & 25.53 & 8.12 & 6.74 & 42.70 \\
\hline
\end{tabular}

Source: authors' calculations based on the reporting documents of the Federal Tax Service of Russia.

Quantitative analysis of tax benefits for sub-federal taxes (based on the decisions taken by the regional authorities) suggests contradictory trends: on the one hand, the total amount of lost revenue of budgets of the regions of North Caucasus Federal District is significantly lower than the national average, but, on the other hand, we have the situation where some subjects are allocated with extremely high levels of total preferences (e.g. Chechnya, Kabardino-Balkaria and Karachay-Cherkessia republic).

An even larger heterogeneity occurs in the context of specific tax benefits:

- The maximum level of regional tariff preferences for the regional property tax takes place in the three abovementioned subjects, ranging from $36.7 \%$ to $50.7 \%$;

- The majority of subjects of the NCFD actively use preferences for the transport tax: in Dagestan the share of benefits is more than $55 \%$ of the current income tax, the Chechen Republic given a low level of granting tariff preferences (about 7.7\%) has zero rate of tax in respect of the most widely used means of transport.

- Local benefits for land tax is very high in Kabardino-Balkar Republic, their share in the proceeds reaches up to $96 \%$, being, on the one hand, one of the instruments to promote the development of agriculture, and on the other - a destabilizing factor of the regional and municipal finance.

In general, the study on the potential of sub-federal taxation of the subjects of the NCFD indicates a dependency elements in the implementation of fiscal policy at the meso level. This situation is especially clearly manifested in the field of taxation powers of subsidized regions that are actively implementing the policy of granting tariff preferences and reduction of interest rates on sub-federal taxes, focused on the correction of budgetary imbalances via additional transfers from the federal center. It is symptomatic that these subjects most widely use fiscal preferences of subnational taxes, being characterized by insufficiently efficient system of tax administration. A significant differentiation in tax collection at the regional level can be traced based on the dynamics of the indicator 'share of debt in tax revenues' (Table 3). 
Table 3. The share of tax arrears accumulated in the actual tax revenues of the North Caucasus Federal District and countrywide in 2010-2013

\begin{tabular}{lcccc}
\hline & \multicolumn{4}{c}{ The ratio between debt and accumulated tax revenues, \% } \\
\cline { 2 - 5 } & 2010 & 2011 & 2012 & 2013 \\
\hline Republic of Dagestan & 28.87 & 54.06 & 44.44 & 39.43 \\
Republic of Ingushetia & 62.61 & 44.11 & 45.41 & 45.63 \\
Kabardino-Balkar Republic & 73.14 & 63.72 & 121.77 & 113.98 \\
Karachay-Cherkess Republic & 19.20 & 18.57 & 27.08 & 30.80 \\
Republic of Northern Ossetia-Alania & 74.95 & 74.87 & 75.44 & 69.96 \\
Chechen Republic & 19.22 & 20.29 & 18.19 & 16.04 \\
Stavropol Krai & 17.42 & 25.54 & 26.84 & 24.80 \\
Total countrywide (average value) & 9.18 & 6.95 & 6.64 & 6.80 \\
\hline
\end{tabular}

Source: based on (Federal State Statistics Service, 2014).

Presented calculations indicate the presence of significant reserves to increase tax revenues of NCFD regions by improving the efficiency of administration, which vary in 2013 from $16 \%$ in the Chechen Republic to $114 \%$ in the Kabardino-Balkar Republic given the national average level of $6.8 \%$. In this case, it is advisable to emphasize that the problems with tax collection are not only administrative, but also of economic nature, being associated with insufficient financial resources generated in the traditional sectors of these regions, and high 'shadow' component (agriculture, trade).

One attribute characteristic for all of these regions is a predominantly agricultural economy, as well as the slow pace of its growth, coupled with a significant level of financial support from the federal budget. This, in turn, also has a strong disincentive for the fiscal efforts, including through the formation of opportunistic behavior of taxpayers and the extremely low efficiency of tax control. At that, in all subjects, except the Chechen Republic and Ingushetia, there is a steady tendency to annual growth of tax arrears. In this situation, it is symptomatic that regions 'succeeded' in setting preferences, have a low fiscal discipline than the entities that implement a more balanced tax policy of granting tariff preferences.

The economic feasibility of the above tactics of tax competition is maintained under soft budget constraints under which the 'shortfall' revenues partially offset by a mechanism of intergovernmental transfers, as evidenced by the field of correlation and the line of regression shown in Figure 1. Note that the Kabardino-Balkaria republic is excluded from the calculations, since its share of debt in tax revenues in 2012 reached 121\%).

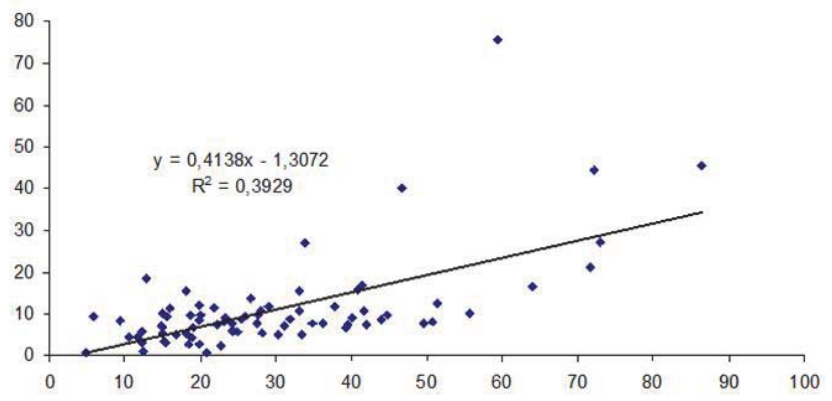

Figure 1. Interrelation between the volume of financial assistance and tax arrears in the Russian regions, 2012 (Dzhurbina \& Fateev, 2014, p. 99)

The resulting distortions of the actual tax burden, especially in sub-federal taxes, negate the necessary feedback between the needs of a particular area of budget resources and the participation of residents and local business structures in the financing of these needs.

The foregoing gives grounds to state that the uneven level of enforcement of tax laws favor an additional factor in the initiation of tax competition. The most pronounced negative trend of erosion of fiscal discipline are taking place in the 
regions-recipients, which do not only more actively accumulate tax arrears, but also implement an opportunistic model of fiscal policy that helps to perpetuate these negative tendencies and partial compensation for their destabilizing influence at the expense of federal transfers.

\section{Conclusion}

Specifics of tax competition in the regions of North Caucasus Federal District, being determined by the shift of its targets from reducing tax rates to towards low tax collection (especially regional and local taxes), compensated to varying degrees by transfers from the federal budget, almost completely eliminates its possible positive effects associated with the rejection of the monopoly model of public goods provision by a unified state body that improve the efficiency of the public sector, while improving fiscal conditions for doing business.

The negative effects of this phenomenon occur within the general trend to consolidate and further strengthen the interregional disparities in tax efficiency, as well as the initiation of the special institutional 'traps', characterized by the causal interdependence of socio-economic development and fiscal effectiveness of individual territories.

This situation requires the activation of the administrative methods of regulation of tax competition between regions that are not efficiently using its own tax potential in a soft budget constraints on the part of the federal government. Under this approach, it is advisable to impose restrictions of powers of the subsidized entities of the Russian Federation to set a low (zero) sub-federal tax rates, as well as greater control over the process of initiating new fiscal preferences.

In order to promote 'fiscal-responsible' behavior of regional authorities, it is proposed to adjust the amount of intergovernmental transfers provided on the amount of 'shortfall' of income arising from unsustainable fiscal solutions of sub-federal authorities, as well as due poor (lower than the national average) level of tax administration. The proposed measures on regulation of tax competition to a greater extent meets the priorities of fiscal federalism, rather than a constant build-up of financial assistance in a context of permanent reduction of fiscal performance of the territories.

\section{References}

Baldwin, R., \& Krugman, P. (2004), Agglomeration, integration and tax harmonisation. European Economic Review, 48, 1-23.

Bradford, D., \& Oates, W. (1971), The analysis of revenue sharing in a new approach to collective fiscal decisions. Quarterly Journal of Economics, 85 (3), 416-439.

Brennan, G., \& Buchanan, J. (1980), The power to tax: analytical foundations of a fiscal constitution. Cambridge: Cambridge University Press.

Dzhurbina, E.M., \& Fateev, D.I. (2014), Regional features of formation of the tax arrears in the Russian economy. Siberian Financial School, 6, 94-99.

Edwards, J., \& Keen, M. (1996), Tax competition and Leviathan. European Economic Review, 40 (1), 113-134.

Fenge, R., \& Wrede, M. (2007), EU financing and regional policy: vertical fiscal externalities when capital is mobile. FinanzArchiv: Public Finance Analysis, 63 (4), 457-476.

Federal State Statistics Service (2014), Russian Finance 2014. Appendix to the collection (the information in the context of the Russian Federation). Moscow: Rosstat. [Online] Available: http://www.gks.ru/free_doc/doc_2014/pril-fin.rar (October 14, 2015).

Tiebout, Ch.M. (1956), A pure theory of local expenditures. Journal of Political Economy, 64 (5), 416-424.

Wildasin, D. (1988), Nash equilibria in models of fiscal competition. Journal of Public Economics, 35, 229-240.

Wilson, J.D. (1986), A theory of interregional tax competition. Journal of Urban Economics, 19 (3), 296-315.

Wilson, J.D. (1999), Theories of tax competition. National Tax Journal, 52 (2), 269-304.

Zodrow, G.R., \& Mieszkowski, P. (1986), Pigou, Tiebout, property taxation and the under-provision of local public goods. Journal of Urban Economics, 19, 356-370. 